Sheryl E. Kimes is a Professor at the School of Hotel Administration, Cornell University. Jochen Wirtz is Associate Professor of Marketing and Director, APEX MBA (Asia-Pacific Executive MBA) Program at the NUS Business School, National University of Singapore. The case was prepared as a basis of class discussion rather than to illustrate effective or ineffective handling of an administration situation.

The cooperation of Jeannette P.T. Ho, who was then the Director of Revenue Management, Raffles the Plaza \& Swissotel The Stamford, Singapore (now Jeannette is the Corporate Director of Revenue Management, Banyan Tree Hotels \& Resorts, Singapore), and Giorgio Olivotti, Restaurant Manager, Prego, are gratefully acknowledged. Selected financial and market data have been disguised for confidentiality reasons. The case writers gratefully acknowledge the excellence assistance of our student researchers Goh Chwee Suan, Handy Amin and Chua Hsiao Wei for the successful completion of the case.

Please address all correspondence to: Jochen Wirtz, Department of Marketing, NUS Business School, National University of Singapore, 1 Business Link, Singapore 117592.E-mail: bizwirtz@nus.edu.sg

\title{
Revenue Management at Prego Italian Restaurant
}

After the busy lunch hours on a weekday afternoon, John, ${ }^{1}$ Prego's restaurant manager, was looking at the halfempty restaurant, feeling that it was in total contrast to the lunch and dinner hours, especially during the weekends, when they had to turn away customers. If seats were occupied during the off-peak hours, more revenue could be generated. During the peak periods, when customer demand exceeded the supply of tables and diners were unwilling to wait for long, Prego was losing revenue and perhaps even future business. John thought that there should be better strategies in which the revenue could be increased. John hired a consultant to help develop a revenue management strategy that would increase revenues without jeopardizing diner satisfaction.

\section{COMPANY BACKGROUND AND MARKET}

\section{ENVIRONMENT}

Prego is an upscale, trendy, and popular Italian restaurant in Singapore. It was rated one of Singapore's Best Restaurants in 2002 by the Singapore Tatler, an authoritative review guide to the local restaurant scene. Prego is located right at the heart of Singapore within the Raffles City complex. Part of the complex are Singapore's largest hotel, the Swissotel The Stamford, a 5-star hotel with 1,261 rooms, Raffles The Plaza, a 51/2-star deluxe hotel with 769 rooms, and the Raffles City Shopping Centre. Prego enjoys a prime central location in the vicinity of Singapore's main shopping area Orchard Road, and the Central Business District. The Raffles City complex is also conveniently accessible by public transport, and is located next to one of Singapore's three main subway train interchanges, the City Hall MRT Interchange².

\footnotetext{
${ }^{1}$ Names of individuals have been disguised.

2"MRT" is the acronym for the Mass Rapid Transit passenger service in Singapore. There are currently 53 train stations linking all areas of the island.
} 
Also, the 3-level basement of the Raffles City complex provides ample parking space. Prego's prominent ground level location, at the busy intersection of Bras Basah Road and Beach Road, making it highly visible to the large volume of passerby traffic.

The restaurant industry in Singapore is fiercely competitive, with restaurants opening and closing on a regular basis. Singapore has a vibrant restaurant industry which accounts for US\$3 billion per year (including sales at hawker stalls). The 799 full-service restaurants accounted for some US\$900 million of the total market; the 245 fast-food restaurants for US\$325 million; and the 198 hotel restaurants for US\$650 million. ${ }^{3}$

Singaporeans eat out frequently. Nearly two-thirds (62.9\%) eat at hawker centers (groups of local food purveyors) at least once a week, while $56.9 \%$ patronize neighborhood coffee shops and $10.5 \%$ go to restaurants at least once a week. ${ }^{4}$ Dining out expenditures increased from $46 \%$ of total average food expenditures in 1988 to $55 \%$ of total average food expenditures in $1998 .{ }^{5}$ The growth in dining out expenditures is attributed to a number of factors including (1) the increased affluence of Singaporeans, especially those under 40 years old, (2) the increase in expatriate residents of Singapore, and (3) lifestyle changes which have caused Singaporeans to prefer increased convenience. A fact sheet on Singapore is provided in Appendix A.

Prego has been successful for over 10 years, and maintained its reputation as an authentic, high quality restaurant. It offers authentic Italian food to tourists, business travelers, expatriates and young Singaporean professionals. Their upscale positioning has contributed to their continuing success.

Prego serves Lunch (11:30 a.m.-2:30 p.m.), Snacks (2:30 p.m.-6:30 p.m.), Dinner (6:30 p.m.-10:30 p.m.), and Supper (10:30 p.m.-12:30 a.m.). The dining area consists of the Bar, Antipasto, Restaurante, Pizzaria, and Alfresco Dining sections, with a total capacity of 340 seats. Exhibit 1 shows the floor plan of Prego. The restaurant also includes a takeaway Deli counter and a waiting area that can accommodate up to twelve diners.

The standard menu comprises approximately eight appetizers and salads, three soups, twenty-seven entrees including pasta, pizza, fish and meat, and seven desserts (see Appendix B). Prego also offers a wide selection of wines from Italy, France, Australia, California and New Zealand. A manager is always on duty. Approximately $20 \%$ of the customers are hotel guests at Swissotel The Stamford and Raffles The Plaza, 30\% are tourists, and the remaining 50\% are local diners.

\footnotetext{
${ }^{3}$ Singapore Department of Statistics (2002), Retail Sales Index and Catering Trade Index December 2002; and Singapore Department of Statistics (2000), Economic Surveys Series - Hotels \& Catering 2000.

${ }^{4} \mathrm{Kau}$, Ah Keng, Tan Soo Jiuan and Jochen Wirtz (1998), 7 Faces of Singaporeans: Their Values, Aspirations and Lifestyles, Singapore: Prentice Hall.

${ }^{5}$ Singapore Department of Statistics. 2002. Retail Sales Index and Catering Trade Index. December 2002; Singapore Department of Statistics. 2000. Economic Surveys Series - Hotel \& Catering 2000.
} 
Exhibit 1: Floor Plan of Prego

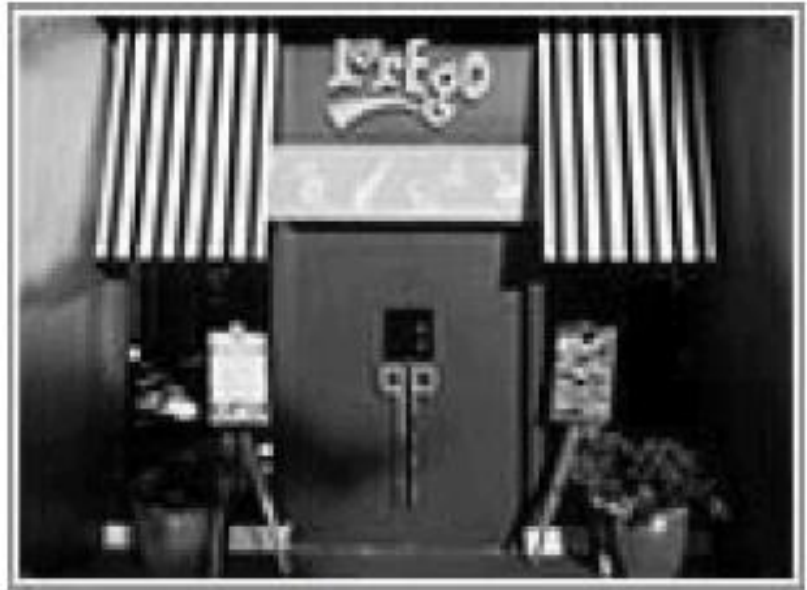

Entrance

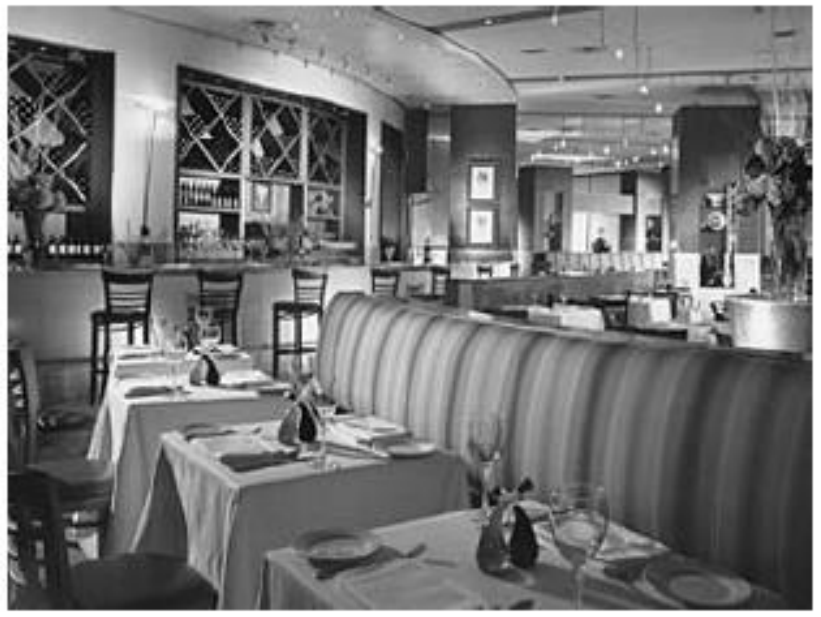

Restaurante

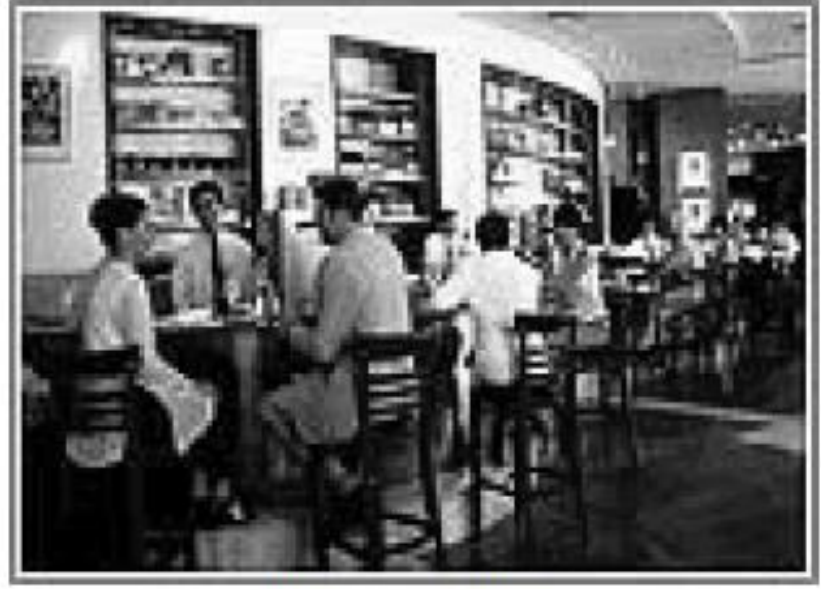

Wine Counter/ Bar

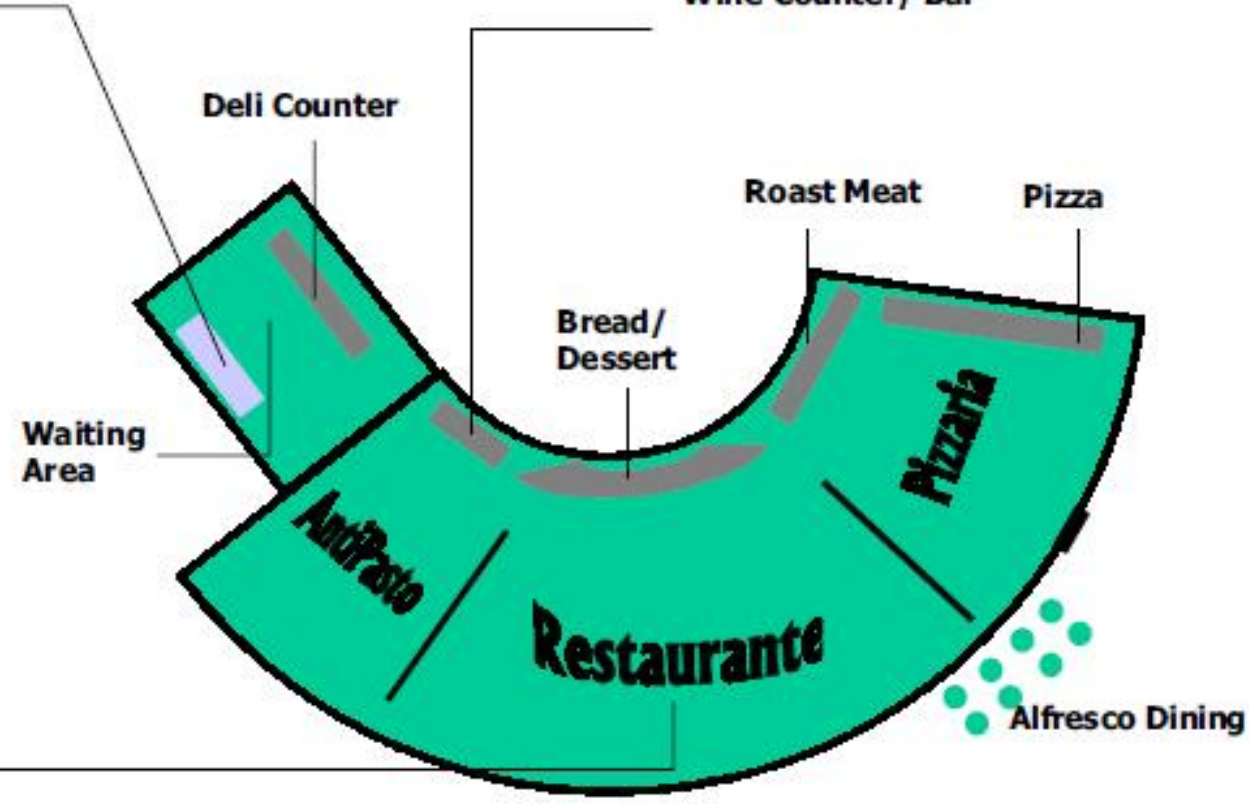




\section{INTRODUCTION TO RESTAURANT REVENUE}

\section{MANAGEMENT}

Revenue management (also known as yield management) was first developed in the mid-1980s and has been successfully applied to the airline and hotel industries for many years, but has only recently been applied to the restaurant industry.

Revenue management is a sophisticated form of supply and demand management. Its primary focus is managing customer demand through the use of variable pricing and capacity management to maximize profitability. The four strategic levers for yield management are: calendar (reservations, bookings), clock (duration controls, turnover rates), capacity (demand smoothing) and pricing (price fences, discounts). Through the application of information technology, pricing strategy, and service product/process design, revenue management helps companies to sell the right product at the right time to the right customer for the right price. ${ }^{6}$

Revenue management is particularly suited for the restaurant industry, with its relatively finite capacity of available tables, perishable inventory, micro-segmented markets of restaurant guests, fluctuating demand, low variable to fixed costs ratios, and services that can be sold in advance through bookings and reservations. ${ }^{7}$

Success in revenue management is typically measured in revenue per available time-based inventory unit. In the airline industry, this becomes revenue per available seat- mile; in the hotel industry, revenue per available room-night; and in the restaurant industry, revenue per available seat- hour (RevPASH). The revenue per available time-based inventory unit can be calculated by multiplying the capacity utilization by the average price.

For a restaurant to be able to apply revenue management, it should (1) establish its baseline performance, (2) understand the causes of performance, (3) develop a revenue management strategy, (4) implement the strategy, and (5) monitor performance. ${ }^{8}$

\section{PREGO DINERS}

\section{Guest Arrival Patterns}

As Prego's arrival patterns differ significantly by half hours during the peak periods, the data was captured on a half hourly basis. Guest arrivals were captured from the opening time of a check. This was an accurate measure of arrival times, since more than $95 \%$ of the checks were opened within five minutes of guest arrival.

Lunch arrivals were heavily centered around 12.30 p.m. and attracted mainly diners on their lunch breaks or those on business lunches. Dinner arrivals were more widely spread between 6.30 to 8.00 p.m. (see Exhibit 2) and attracted

\footnotetext{
${ }^{6}$ Kimes, Sheryl E., and Jochen Wirtz. 2003. Has Revenue Management Become Acceptable? Findings from an International Study on the Perceived Fairness of Rate Fences, Journal of Service Research. 6(3).

${ }^{7}$ Kimes, Sheryl E., Richard B. Chase, Sunmee Choi, Philip Lee, and Elizabeth Ngonzi. 1998. Restaurant Revenue Management: Applying Yield Management to the Restaurant Industry, Cornell Hotel and Restaurant Administration Quarterly. 39(3): 32-39.

${ }^{8}$ Kimes, Sheryl E. 1999. Implementation of Restaurant Revenue Management: A Five-Step Approach, Cornell Hotel and Restaurant Administration Quarterly. 40(3): 15-22.
} 
mainly couples and working executives. On weekends groups of friends and families were more prevalent. The restaurant received relatively few shoppers and in-house guests (i.e., guests that stayed in one of the two hotels located in the Raffles City complex).

\section{Exhibit 2: Guest Arrival Patterns}

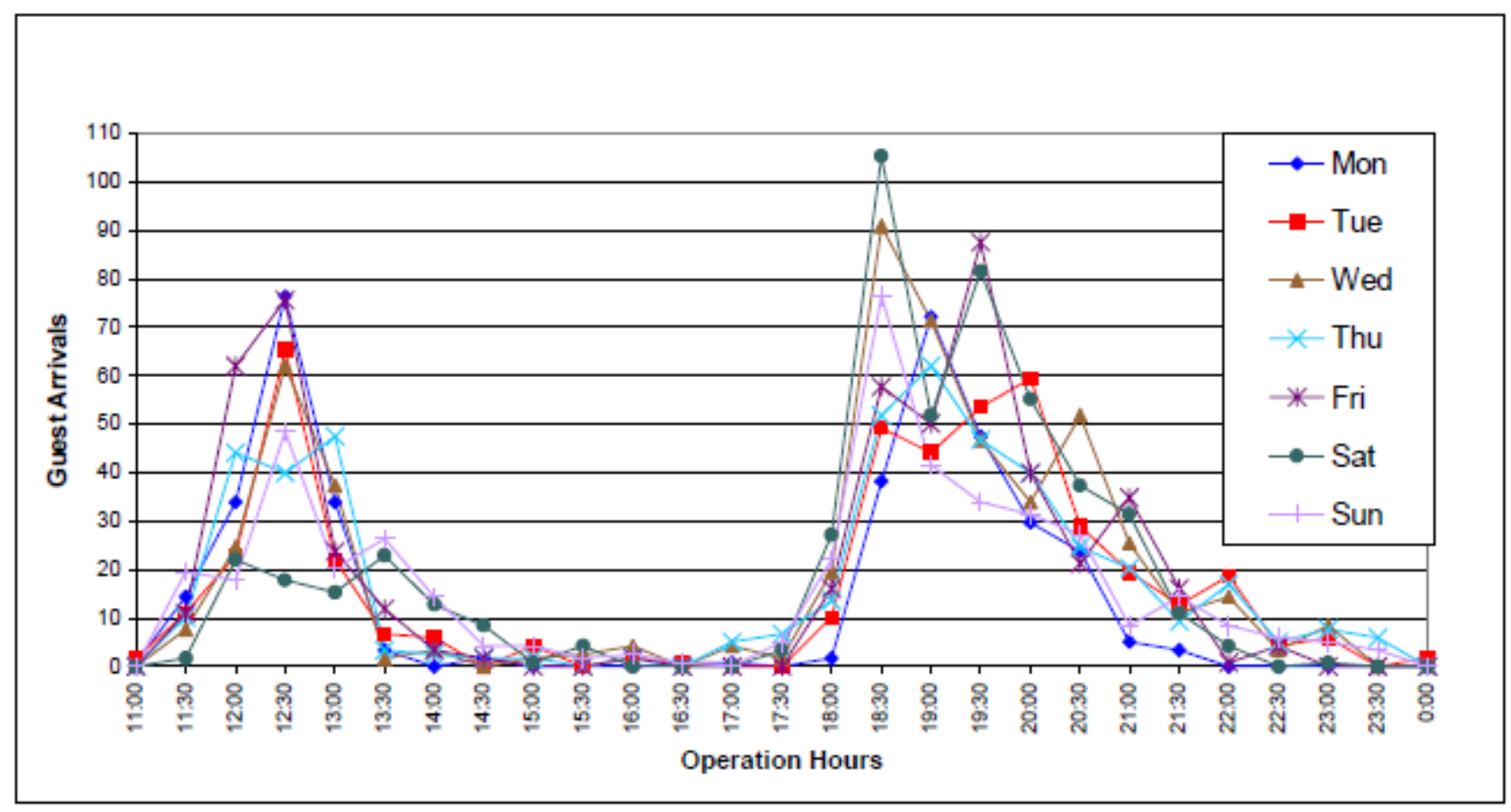

A sample of the collected data on the pattern of dinner guest arrivals and revenues, per half-hour periods, for two weeks is provided in Exhibit 3 and is also available in the file prego.xls.

Hostesses recorded the names of waiting diners who could not immediately be given a table. Prego found that approximately fifteen to thirty customers could not be accommodated immediately for dinners from Tuesdays to Saturdays. Of those asked to wait, approximately 33\% did not wait and left for other restaurants. Diners with reservations were rarely turned away, as all reservations were accepted and honored.

\section{Meal Duration}

Both the mean and the standard deviation of meal duration for peak times were recorded and are shown in Exhibits 4 and 5. The average dining time was approximately one hour and twenty-five minutes with a standard deviation of thirtyseven minutes. Means and standard deviations varied by half-hour periods and by day of week 
Exhibit 3: Sample Guest Arrivals — Dinner

\begin{tabular}{|c|c|c|c|c|c|c|c|c|c|}
\hline \multirow{2}{*}{ Day of Week } & \multicolumn{8}{|c|}{ Arrival Times } & \multirow{2}{*}{$\begin{array}{l}\text { Dinner } \\
\text { Revenue }\end{array}$} \\
\hline & $18: 00$ & $18: 30$ & $19: 00$ & $19: 30$ & $20: 00$ & $20: 30$ & $21: 00$ & $21: 30$ & \\
\hline Monday & 3 & 59 & 88 & 37 & 36 & 24 & 10 & 7 & $\$ 10,301.32$ \\
\hline Tuesday & 15 & 51 & 53 & 51 & 42 & 31 & 36 & 14 & $\$ 11,470.39$ \\
\hline Wednesday & 14 & 90 & 73 & 42 & 39 & 73 & 25 & 19 & $\$ 14,658.84$ \\
\hline Thursday & 24 & 59 & 61 & 53 & 42 & 17 & 8 & 15 & $\$ 11,493.06$ \\
\hline Friday & 10 & 39 & 56 & 75 & 27 & 27 & 46 & 25 & $\$ 10,501.53$ \\
\hline Saturday & 15 & 117 & 14 & 70 & 51 & 32 & 32 & 14 & $\$ 13,543.46$ \\
\hline Sunday & 31 & 58 & 53 & 15 & 36 & 19 & 17 & 8 & $\$ 8,052.16$ \\
\hline Monday & 0 & 17 & 56 & 58 & 24 & 24 & 0 & 0 & $\$ 6,462.71$ \\
\hline Tuesday & 5 & 48 & 36 & 56 & 76 & 27 & 3 & 12 & $\$ 13,085.65$ \\
\hline Wednesday & 25 & 92 & 70 & 51 & 29 & 31 & 25 & 3 & $\$ 12,328.54$ \\
\hline Thursday & 3 & 44 & 63 & 41 & 37 & 32 & 32 & 3 & $\$ 11,121.85$ \\
\hline Friday & 22 & 76 & 44 & 100 & 53 & 15 & 24 & 7 & $\$ 12,702.21$ \\
\hline Saturday & 39 & 93 & 90 & 93 & 59 & 42 & 31 & 8 & $\$ 14,398.04$ \\
\hline Sunday & 14 & 95 & 31 & 53 & 27 & 36 & 0 & 20 & $\$ 10,230.51$ \\
\hline
\end{tabular}

Exhibit 4: Lunch Meal Duration - Mean and Standard Deviation

\begin{tabular}{|l|c|c|c|c|}
\hline \multirow{2}{*}{ Day of Week } & \multicolumn{4}{|c|}{ Arrival Times } \\
\cline { 2 - 5 } & $\begin{array}{c}12: 00 \\
\text { Duration (STD) }\end{array}$ & $\begin{array}{c}12: 30 \\
\text { Duration (STD) }\end{array}$ & $\begin{array}{c}13: 00 \\
\text { Duration (STD) }\end{array}$ & $\begin{array}{c}13: 30 \\
\text { Duration (STD) }\end{array}$ \\
\hline Monday & $1: 14(0: 29)$ & $1: 01(0: 20)$ & $0: 51(0: 17)$ & $0: 22(0: 05)$ \\
\hline Tuesday & $1: 23(0: 21)$ & $1: 19(0: 28)$ & $1: 15(0: 26)$ & $0: 49(0: 07)$ \\
\hline Wednesday & $1: 12(0: 41)$ & $1: 05(0: 22)$ & $0: 53(0: 12)$ & $0: 30(0: 05)$ \\
\hline Thursday & $1: 28(0: 30)$ & $1: 13(0: 44)$ & $0: 49(0: 15)$ & $0: 20(0: 05)$ \\
\hline Friday & $1: 10(0: 34)$ & $1: 17(0: 23)$ & $0: 50(0: 19)$ & $1: 20(0: 11)$ \\
\hline Saturday & $1: 04(0: 25)$ & $1: 19(0: 22)$ & $0: 50(0: 07)$ & $1: 22(0: 22)$ \\
\hline Sunday & $1: 09(0: 18)$ & $1: 25(0: 34)$ & $1: 17(0: 19)$ & $1: 19(0: 27)$ \\
\hline
\end{tabular}


Exhibit 5: Dinner Meal Duration — Mean and Standard Deviation

\begin{tabular}{|l|c|c|c|c|c|c|}
\hline \multirow{2}{*}{ Day of Week } & \multicolumn{7}{|c|}{ Arrival Times } \\
\cline { 2 - 7 } & $\begin{array}{c}18: 00 \\
\text { Duration } \\
(\mathrm{STD})\end{array}$ & $\begin{array}{c}18: 30 \\
\text { Duration } \\
(\mathrm{STD})\end{array}$ & $\begin{array}{c}19: 00 \\
\text { Duration } \\
(\mathrm{STD})\end{array}$ & $\begin{array}{c}19: 30 \\
\text { Duration } \\
(\mathrm{STD})\end{array}$ & $\begin{array}{c}20: 00 \\
\text { Duration } \\
(\mathrm{STD})\end{array}$ & $\begin{array}{c}20: 30 \\
\text { Duration } \\
(\mathrm{STD})\end{array}$ \\
\hline Monday & - & $1: 22(0: 24)$ & $1: 13(0: 38)$ & $1: 08(0: 27)$ & $1: 11(0: 19)$ & $0: 46(0: 17)$ \\
\hline Tuesday & $1: 58(0: 25)$ & $1: 09(0: 23)$ & $1: 10(0: 31)$ & $1: 27(0: 40)$ & $1: 34(0: 33)$ & $1: 14(0: 34)$ \\
\hline Wednesday & $1: 23(0: 38)$ & $1: 15(0: 39)$ & $1: 13(0: 34)$ & $1: 08(0: 40)$ & $1: 21(0: 24)$ & $1: 09(0: 33)$ \\
\hline Thursday & $1: 20(0: 08)$ & $1: 11(0: 33)$ & $1: 12(0: 43)$ & $1: 32(0: 41)$ & $1: 18(0: 37)$ & $1: 16(0: 23)$ \\
\hline Friday & $1: 20(0: 27)$ & $0: 48(0: 29)$ & $1: 23(0: 31)$ & $1: 22(0: 43)$ & $1: 11(0: 40)$ & $1: 02(1: 10)$ \\
\hline Saturday & $1: 20(0: 25)$ & $1: 20(0: 42)$ & $1: 10(0: 27)$ & $1: 07(0: 44)$ & $1: 25(0: 24)$ & $1: 18(0: 23)$ \\
\hline Sunday & $0: 55(0: 22)$ & $0: 50(0: 30)$ & $1: 23(0: 45)$ & $1: 17(0: 28)$ & $1: 10(0: 30)$ & $1: 20(0: 17)$ \\
\hline
\end{tabular}

Exhibit 6: Course Timing - Mean and Standard Deviation

\begin{tabular}{|l|c|c|c|c|}
\hline \multirow{2}{*}{ Course Timing } & \multicolumn{4}{|c|}{ Day of Week } \\
\cline { 2 - 5 } & $\begin{array}{c}\text { Wednesday } \\
\text { Duration (STD) }\end{array}$ & $\begin{array}{c}\text { Thursday } \\
\text { Duration (STD) }\end{array}$ & $\begin{array}{c}\text { Friday } \\
\text { Duration (STD) }\end{array}$ & $\begin{array}{c}\text { Saturday } \\
\text { Duration (STD) }\end{array}$ \\
\hline $\begin{array}{l}\text { Arrival to } \\
\text { Seating }\end{array}$ & $0.03(0.01)$ & $0.04(0.02)$ & $0.03(0.02)$ & $0.03(0.01)$ \\
\hline $\begin{array}{l}\text { Seating to } \\
\text { Order }\end{array}$ & $0.05(0.02)$ & $0.04(0.01)$ & $0.04(0.02)$ & $0.04(0.03)$ \\
\hline $\begin{array}{l}\text { Order to } \\
\text { Appetizer }\end{array}$ & $0.09(0.02)$ & $0.10(0.04)$ & $0.11(0.03)$ & $0.09(0.03)$ \\
\hline $\begin{array}{l}\text { Appetizer to } \\
\text { Entrée }\end{array}$ & $0.15(0.05)$ & $0.14(0.08)$ & $0.16(0.04)$ & $0.14(0.04)$ \\
\hline $\begin{array}{l}\text { Entrée to } \\
\text { Dessert }\end{array}$ & $0.30(0.10)$ & $0.31(0.08)$ & $0.28(0.05)$ & $0.32(0.07)$ \\
\hline $\begin{array}{l}\text { Dessert to } \\
\text { Check Request }\end{array}$ & $0.14(0.04)$ & $0.15(0.03)$ & $0.18(0.08)$ & $0.16(0.03)$ \\
\hline $\begin{array}{l}\text { Check Request to } \\
\text { Check Clearance }\end{array}$ & $0.03(0.02)$ & $0.03(0.02)$ & $0.03(0.01)$ & $0.04(0.02)$ \\
\hline $\begin{array}{l}\text { Check Clearance } \\
\text { to Departure }\end{array}$ & $0.02(0.01)$ & $0.03(0.02)$ & $0.04(0.03)$ & $0.03(0.01)$ \\
\hline $\begin{array}{l}\text { Arrival to } \\
\text { Departure }\end{array}$ & $1.21(0.124)$ & $1.24(0.129)$ & $1.27(0.115)$ & $1.25(0.090)$ \\
\hline
\end{tabular}




\section{Course Timing}

Measurement was carried out by conducting a detailed timing study of ten random tables (with fewer than six diners) per dinner sitting for each of the days from Wednesday through Saturday. Courses timed included (1) arrival to seating/ drinks, (2) seating/ drinks to food order, (3) food order to appetizer, (4) appetizer to entree, (5) entree to dessert/coffee, (6) dessert/coffee to check request, (7) check request to check clearance, (8) check clearance to leaving table, and (9) arrival to departure. The findings are shown in Exhibit 6.

\section{Revenue per Available Seat Hour (RevPASH)}

Not surprisingly, the RevPASH performance (see Exhibit 7) followed the arrival patterns, with the highest RevPASH being achieved between 12:30 to 13:30 p.m., and between 19:00 to 21:00 p.m. The afternoon period between 14:30 to 17:30 p.m. showed very little activity.

\section{Exhibit 7: RevPASH Patterns}

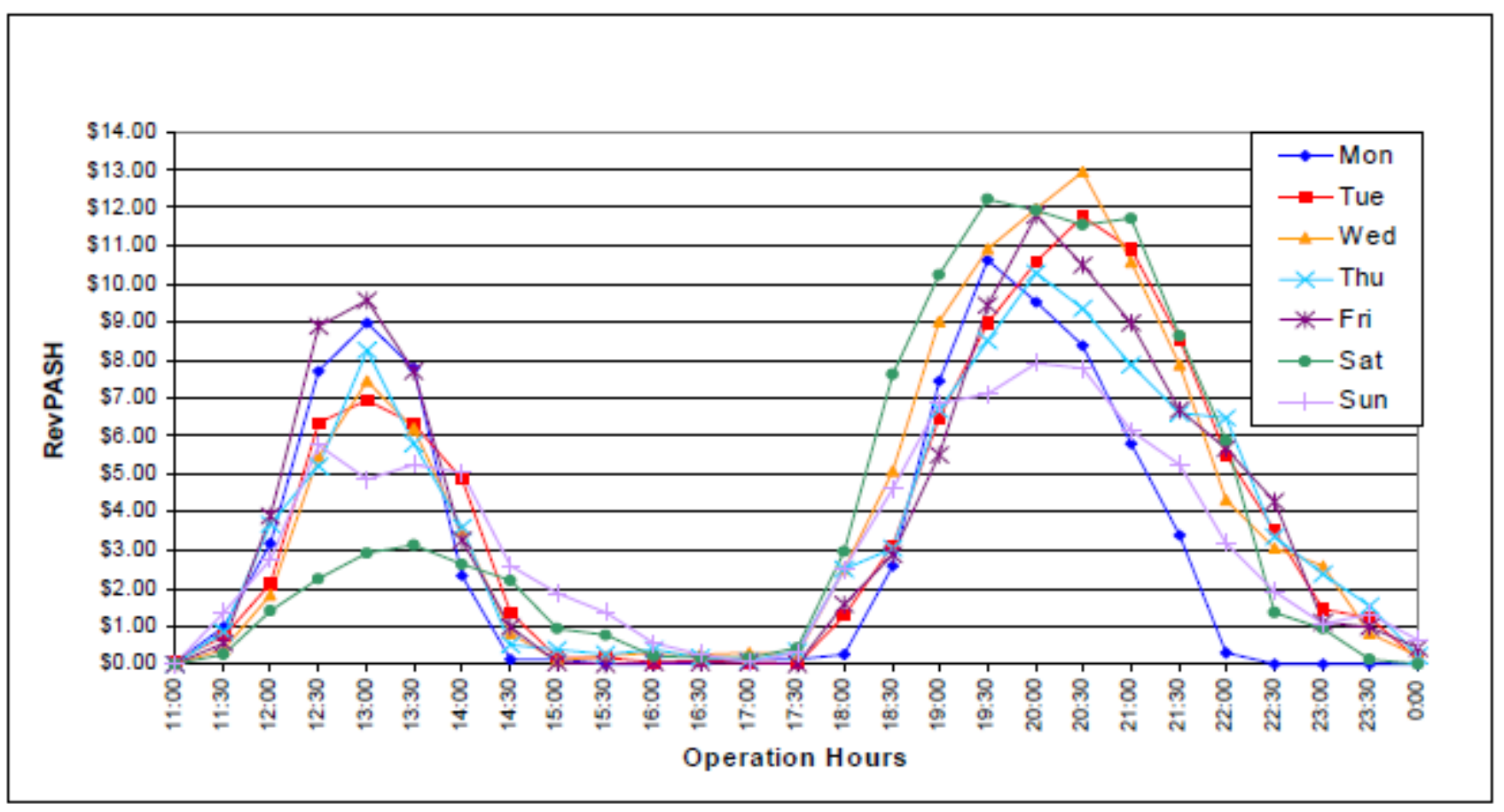




\section{SERVICE BLUEPRINT OF PREGO}

A service blueprint for Prego was developed by a consultant (Exhibit 8). It shows the individual steps of the whole dining process starting from making reservations to departure.

Exhibit 8: Service Blueprint

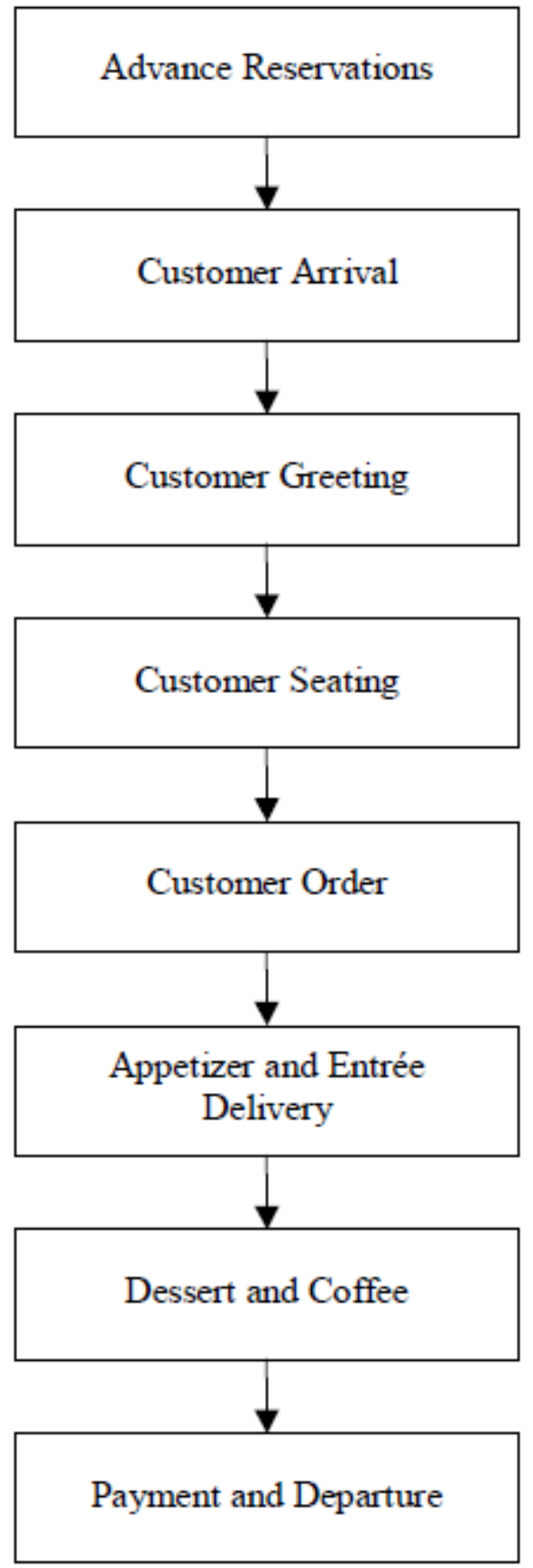




\section{Advance Reservations}

Phone reservations were taken as long as tables were still available, at the exact time requested by the customer. No credit card guarantees were asked, except for special occasions like Valentine's Day, Christmas Eve, New Year's Eve and Chinese New Year.

\section{Customer Arrival}

Reservations generally accounted for about 50 to $60 \%$ of all arrivals, with an even higher proportion on peak days. When a table becomes available near the reserved time, the table was "held" even when other guests were waiting to be seated. If a customer with reservations was late or did not show up, the reserved table might have been sitting empty for some time even though other guests were waiting. Prego had approximately nine or ten no-show parties on a typical weekday, and around thirteen no-show tables on a typical weekend.

\section{Customer Greeting}

This was handled by two or three hosts stationed at the entrance. These hosts were responsible for the flow of tables and must track when tables become available. However, Prego had no table management system and the large size of the restaurant often made it difficult for the hosts to know which ones were available. The hosts relied on servers to notify them about available tables and sometimes there was a significant time lag before a server was free to go to the entrance to pick up new diners. Often, the hosts had to leave the entrance to find available tables.

\section{Customer Seating}

Once a table became available, the host was notified and tried to find the next party on the waiting list. There were often lags between the time when the table was ready and when the host was notified, and until the waiting party was identified.

\section{Customer Order}

Drink orders were taken first. Once the drinks were delivered, food orders were then taken. With the wide variety of wines and food available, customers may spend quite some time deciding.

\section{Appetizer and Entree Delivery}

The kitchen was comprised of three sections (Hot, Cold, and Dessert and Rotis), which made it difficult to coordinate common delivery times at the diners' tables. Two back runners and one or two front runners were deployed to run food to the serving stations. Courses which had become cold after being left waiting for too long on the counter had to be redone. The servers handled ordering, serving, occasional food running, check clearance and bussing. This saved on overall labor requirements but was extremely challenging to operate during peak times. The high staff turnover prevalent in the restaurant industry made it difficult to adequately train all the new staff and casuals on the variety of tasks. Often there were times when the restaurant operated on $50 \%$ casuals.

\section{Dessert and Coffee}

The restaurant tried to use suggestive selling to increase the average check and guests were encouraged to order dessert 
and coffee, even during peak hours.

\section{Payment and Departure}

Most payments were done via credit card, which took longer to process than other payment methods. Delays could occur Exhibit 9: Monthly Profit \& Loss Statement

\begin{tabular}{lrr} 
REVENUE: & & \\
Food & $\$ 322,718$ & $73.8 \%$ \\
Beverage & $\$ 114,827$ & $26.2 \%$ \\
\hline Total Revenues & $\$ 437,545$ & $100.0 \%$ \\
\hline
\end{tabular}

\section{COSTS:}

Variable Costs:

$\begin{array}{lll}\text { Cost of Food } & \$ 96,882 & 22.1 \%\end{array}$

$\begin{array}{lrr}\text { Cost of Beverages } & \$ 28,232 & 6.5 \%\end{array}$

\begin{tabular}{lcc}
\hline Total Variable Costs & $\$ 125,114$ & $28.6 \%$
\end{tabular}

Fixed Costs:

Rental of Premises

Depreciation of Furnature, Fittings \& Equipment

$\$ 104,528 \quad 23.9 \%$

Total Labour Costs

$\$ 5,713 \quad 1.3 \%$

Laundry

$\$ 121,111 \quad 27.7 \%$

Linen (Table Cloths \& Napkins)

$\$ 4,146 \quad 0.9 \%$

Uniforms

$\$ 1,164 \quad 0.3 \%$

Breakage \& Utensil Replacement

Cleaning Services \& Materials

$\$ 748 \quad 0.2 \%$

$\$ 49 \quad 0.0 \%$

Utilities (Electricity, Water \& Gas)

$\$ 1,360 \quad 0.3 \%$

Telecoms

$\$ 1,521 \quad 0.3 \%$

Music \& Entertainment

$\$ 316 \quad 0.1 \%$

Printing, Stationary \& Menus

Advertising \& Promotion

$\$ 732 \quad 0.2 \%$

Miscellaneous

$\$ 3,722 \quad 0.9 \%$

Total Variable Costs

$\$ 2,512 \quad 0.6 \%$

$\$ 2,502 \quad 0.6 \%$

\begin{tabular}{lcc}
\hline Total Costs & $\$ 375,240$ & $85.8 \%$ \\
\hline Gross Operating Profit & & \\
\hline \hline & $\$ 62,305$ & $14.2 \%$ \\
Food Costs/Food Revenues & $30.0 \%$ & \\
Beverage Costs/Beverage Revenues & $24.6 \%$ & \\
Total Number of Covers & 13,259 & \\
Average Check & $\$ 33.00$ & \\
REVPASH & $\$ 3.30$ &
\end{tabular}

Note: The data are based on authors' estimates, and would be typical for an Italian restaurant of Prego's size and location in Singapore. 
when customers could not attract the server's attention, when staff prepared the check and delivered it to the diner, and when processing the payment. After payment, some customers chose to linger at their tables for a bit longer before departing.

\section{DEVELOPING A STRATEGY TO MAXIMIZE REVENUE}

Prego's monthly Profit \& Loss Statement and financial status are shown in Exhibit 9. The Profit \& Loss Statement shows that Prego had a contribution margin ratio of about $71.4 \%$ per dollar of revenue; fixed costs were at a monthly average of $\$ 250,126$. The breakeven point was at about $\$ 350,317$ per month, or an estimate of 10,616 covers. Profit margins were approximately $14.2 \%$ of total revenues.

John's main concern is to increase revenue and contribution by filling up the tables during off-peak periods and to reach higher turnover of tables without affecting customer satisfaction during peak periods. John understands that to be able to achieve it, it not only requires a well planned and creative strategy, but also a careful implementation that does not alienate customers and staff.

Suppose Prego hired you as a consultant to help them develop and implement a strategy to increase revenue and contribution. Use the financial data given, assess the potential revenue and profit impact of potential revenue management measures Prego should consider, and make any logical assumptions needed for doing this. Next, consider the potential customer and staff responses to these potential measures.

Finally, given the potential profit impact and customer and staff responses, what revenue management measures would you recommend that Prego implement, and what should Prego do to minimize potential customer and employee conflicts resulting from these measures? 
APPENDIX A: SINGAPORE FACT SHEET

\section{GEOGRAPHIC DATA}

\begin{tabular}{ll}
\hline Location & South-eastern Asia, islands between Malaysia and Indonesia \\
\hline Land Area & $692.7 \mathrm{sq} . \mathrm{km}$ \\
\hline Climate & $\begin{array}{l}\text { Tropical; hot, humid, rainy; two distinct monsoon seasons - } \\
\text { Northeastern monsoon from December to March and Southwestern } \\
\text { monsoon from June to September; inter-monsoon - frequent } \\
\text { afternoon and early evening thunderstorms }\end{array}$ \\
\hline
\end{tabular}

SINGAPORE'S PEOPLE

\begin{tabular}{|c|c|}
\hline Population & $4,452,732$ (July 2002 est.) \\
\hline Age structure & $\begin{array}{l}0-14 \text { years: } 17.6 \% \text { (male } 404,212 \text {; female } 378,660) \\
15-64 \text { years: } 75.3 \% \text { (male } 1,630,696 \text {; female } 1,724,532) \\
65 \text { years and over: } 7.1 \% \text { (male } 137,512 ; \text { female } 177,120) \text { (2002 est.) }\end{array}$ \\
\hline Population growth rate & $3.46 \%$ (2002 est.) \\
\hline Life expectancy at birth & $\begin{array}{l}\text { Total population: } 80.29 \text { years } \\
\text { female: } 83.47 \text { years }(2002 \text { est.) } \\
\text { male: } 77.34 \text { years }\end{array}$ \\
\hline Ethnic groups & Chinese $76.7 \%$, Malay $14 \%$, Indian $7.9 \%$, other $1.4 \%$ \\
\hline Religions & $\begin{array}{l}\text { Buddhist (Chinese), Muslim (Malays), Christian, Hindu, Sikh, } \\
\text { Taoist, Confucianist }\end{array}$ \\
\hline Languages & $\begin{array}{l}\text { Chinese (official), Malay (official and national), Tamil (official), } \\
\text { English (official) }\end{array}$ \\
\hline $\begin{array}{l}\text { Literacy rate (population } 15 \\
\text { years and older) }\end{array}$ & $93.5 \%$ \\
\hline
\end{tabular}

\section{ECONOMY}

\begin{tabular}{ll}
\hline GDP at current market prices & Purchasing power parity $-\$ 106.3$ billion (2001 est.) \\
\hline GDP - real growth rate & $-2 \%$ (2001 est.) \\
\hline $\begin{array}{l}\text { GDP - per capita at current } \\
\text { market prices }\end{array}$ & Purchasing power parity $-\$ 24,700$ (2001 est.) \\
\hline Inflation rate & $2 \%(2001$ est.) \\
\hline Labour force & 219 million (2000) \\
\hline Unemployment rate & $5 \%(2001$ est.) \\
\hline
\end{tabular}

Sources and further information can be found at http://www.odci.gov/cia/publications/factbook/geos/sn.html 


\section{APPENDIX B: PREGO'S MENU}

\section{ANTIPASTI E INSALATE/ APPETIZERS AND SALADS}

CARPACCIO DI MANZO

$\$ 18.50$

Sliced raw beef, shavings of Parmesan, artichoke button

in lemon dressing and parsley jus

CALAMARI FRITTI

$\$ 17.00$

Deep-fried squid rings served with spicy tartar sauce

VITELLO TONNATO

$\$ 18.50$

Thinly sliced roasted veal served with tuna sauce

INSALATA DEL GOBBO

$\$ 16.50$

Mixed salad with avocado, roasted bell peppers, buffalo mozzarella,

plum tomato, bread croutons and whole egg in Italian dressing

*PARMIGIANA DI MELANZANE

$\$ 16.50$

Baked eggplant layers in tomato salsa with Parmesan cheese

*PORTOBELLO ALLA GRIGLIA

$\$ 17.00$

Grilled Portobello mushroom with arugula salad in balsamico dressing

FEGATO D'OCA

$\$ 32.00$

Pan-Fried Gooseliver served on apple chutney and caramelized onion in red wine sauce, green bell pepper jus

ARAGOSTA E AVOCADO

$\$ 20.50$

Marinated Lobster pieces with avocado and arugula in cocktail sauce

\section{LE ZUPPE / SOUPS}

"MINESTRONE DI VERDURE

$\$ 10.50$

Vegetable soup with basil pesto and glazed Parmesan focaccia bread

$\$ 14.00$

CACIUCCO ALLA LIVORNESE

Fish stew 'Livorno style'

ZUPPA DEL GIORNO

$\$ 10.00$

Today's Soup (we'll tell you) 


\section{RISO/RICE}

RISOTTO CON SPUGNOLE, POLLO E POMODORINI ARROSTITI

$\$ 20.50$

Arborio rice with Morrel mushrooms, chicken thigh and

oven roasted cherry tomatoes

RISOTTO ALLE VENDURE CON GAMBERI DI FIUMME E TARTUFO NERO

$\$ 20.50$

Arborio rice with mixed vegetable, fresh water shrimps meat and black truffle

*VEGETARIAN DISHES

Minimum order — One dish per person!

Service charge and government taxes additional

\section{CHOOSE A PASTA WITH YOUR FAVOURITE SAUCE}

PASTA

SPAGHETTI, LINGUINE, CANNOLICCHI, PAPPARDELLE, PENNE, SAGNE

VONGOLE $\quad: \quad$ Clams in white wine

$\$ 18.50$

FRUTTI DI MARE $\quad: \quad$ Mixed seafood in tomato $\quad \$ 19.50$

FUNGHI PORCINI ： Garlic, Italian parsley, boletus mushroom $\quad \$ \mathbf{\$ 1 8 . 5 0}$

DON GIOVANNI : $\quad$ Chicken thigh, onion, asparagus in avocado cream $\quad \$ \mathbf{\$ 1 8 . 5 0}$

$\begin{array}{lll}\text { ARRABBIATA } & : & \text { Spicy tomato with olives }\end{array}$

CON OLIVE

\section{LA PASTA FRESCA/HOMEMADE PASTA}

*CANNELLONI GRATINATI RIPIENI DI MAGRO E VERDURE

Cannelloni stuffed with cheese and mixed vegetables on tomato sauce, gratinated in béchamel

RAVIOLI CON ANATRA E PORCINI AL BURRO E SALVIA

$\$ 22.00$

Stuffed ravioli with duck meat and boletus mushrooms

In clarified butter and duck gravy

LASAGNE AL FORNO

$\$ 19.00$

Oven-baked layers of pasta with minced beef, tomato béchamel

and Parmesan cheese 
"LAGANELLE CON BATTUTO DI VEGETALI AL GORGONZOLA

Long flat noodle with mixed vegetables in gorgonzol a cheese sauce

TRENETTE CON RAGUE DI FAGIANO

$\$ 20.50$

Triangle shape hollow noodle in Pheasant ragout

CAPELLINI CON BOTTARGA DI TONNO

$\$ 19.00$

Angel hair pasta with dried tuna egg, garlic and olive oil

ORECCHIETTE CON SALMONE AFFUMICATO, CREMA ALLA MELA VERDE

$\$ 18.50$

Tri colour noodles with smoked salmon in green apple cream sauce

FETTUCCINE CON ARAGOSTA

$\$ 22.50$

Fettuccine noodles with lobster pieces, green asparagus and artichoke in saffron sauce

*GNOCCHI DI SPINACI CON POMODORO E BASILICO

$\$ 18.50$

Spinach gnocchi in tomato basil sauce

*VEGETARIAN DISHES

Minimum order — One dish per person!

Service charge and government taxes additional

\section{PESCI E CROSTACEI / FISH AND CRUSTACEANS}

STOCCAFISSO AL VAPORE

$\$ 28.50$

Steamed cod served on broccoli mousse with deep fried celery root,

capers-lemon and red bell peppers salsa in watercress pesto

IPPOGLOSSO AL VAPORE

$\$ 28.50$

Steamed halibut served on white bean puree, tomato confit

and baby leek in bell pepper coulis

SALMONE ALLA PIASTRA

Pan fried medallions of salmon served with braised endives, steamed purple potato and green asparagus in orange fennel salsa

CODA D'ARAGOSTA AI FERRI

$\$ 45.00$

Grilled rock lobster tail served with eggplant, leek and steamed potato

in rosemary garlic oil

BRANZINO ALLA GRIGLIA

$\$ 28.00$

Grilled seabass fillet served with vegetable caponata in extra virgin olive oil 


\section{LE CARNI/ MEAT}

OSSO BUCO CON PUREA DI PATATE

Braised veal shank served with garlic mashed potato

and Parmesan crust cremolata

FILETTO DI MANZO ALLA GRIGLIA

$\$ 31.50$

Grilled beef tenderloin and roasted vegetables in red wine olive oil sauce

CARRE D'AGNELLO ALLA PIASTRA

$\$ 31.00$

Roasted lamb loin served on pan-fried potato, grilled zucchini

with black olive caponata and dried tomato salsa

\section{DALLA ROSTICCERIA/FROM THE ROTISSERIE}

POLLO ALLO SPIEDO

$\$ 29.00$

Spit roasted baby chicken served with sauteed spinach

and roasted potatoes in garlic gravy

SELLA DI CERVO GRIGLIATO CON SALSA DI GINEBRO

Grilled venison loin in juniper berry sauce wi th daily vegetables

CINGHIALE ARROSTO

$\$ 23.50$

Roasted wild boar served with daily vegetables

*VEGETARIAN DISHES

Minimum order — One dish per person!

Service charge and government taxes additional

\section{LE PIZZE / PIZZAS}

GO-GO

$\$ 18.50$

Pepperoni sausage, bell peppers and braised chicory

Boiled egg, tuna, spinach, capers and anchovy

Arugola, parmesan shaves, mixed mushrooms and roasted garlic 
Smoked salmon, grilled zucchini, black olives and sour cream

BOMBA

$\$ 19.50$

Folded and stuffed with smoked turkey breast, button mushroom, topped with basil pesto and Parmesan cheese

\section{DOLCI / DESSERTS}

TIRAMISU

Layers of sponge cake and Mascarpone cheese flavoured with coffee

MUD PIE

Kahlua flavoured ice cream with chocolate cookie

served with caramel and vanilla sauce

CRÈME BRULÉ ALL'AMARETTO

Amaretto cream brulee with almond milk ice cream

CROSTATINA TIEPIDA ALLE MELE CON SALSA AL SIDRO

Apple tart served with cider sauce and vanilla ice cream

MOUSSE AI CIOCCOLATO E LAMPONI

Milk chocolate and raspberry mousse,

citrus biscuit and chocolatenated berries

PANNACOTTA ALLE FRAGOLE

Strawberry pannacotta

GELATI E SORBETTI MISTI

Assorted Italian ice cream and sherbet

FRUTTA FRESCA

$\$ 10.00$

Fruit platter

*VEGETARIAN DISHES

Minimum order — One dish per person!

Service charge and government taxes additional 